\title{
Conserving the endemic birds on the Comoro Islands, III: bird diversity and habitat selection on Ngazidja
}

\author{
JAN STEVENS, MICHEL LOUETTE, LUC BIJNENS and \\ MARC HERREMANS
}

\begin{abstract}
Summary
Bird species diversity is investigated in different habitat types on Ngazidja (Grand Comoro), Comoro Islands. Total bird diversity does not differ significantly among different forest types, but the proportion of endemic species, endemic subspecies and non-endemic species does. Both intact mature forests and pioneer forests on the slopes of Mount Karthala are important for the preservation of bird endemism. The forests on La Grille are poor in endemic species, but their bird species diversity is high thanks to non-endemics. Planting of Eucalyptus is useless for endemic birds. Humblotia flavirostris, Turdus bewsheri and Nesillas brevicaudata avoid logged forests, but Alectroenas sganzini is numerous in them. Foudia eminentissima is common in forests with bananas planted in the undergrowth.
\end{abstract}

La diversité en espèces d'oiseaux est étudiée dans différents habitats à Ngazidja (Grande Comore), Iles Comores. La diversité totale ne varie pas d'une manière significative parmi les différents types de forêt, mais la fraction due aux espèces endémiques, aux sous-espèces endémiques et aux espèces non-endémiques varie. Aussi bien les forêts intactes et matures et les forêts jeunes sur lave sont importantes pour la préservation d'oiseaux endémiques sur les flancs du Mont Karthala. Les forêts à La Grille sont pauvres en oiseaux endémiques, mais leur diversité est grande, grace aux espèces non-endémiques. Les plantations d'Eucalyptus n'ont pas de valeur pour les oiseaux endémiques. Humblotia flavirostris, Turdus bewsheri et Nesillas brevicaudata évitent les forêts exploitées pour le bois, mais Alectroenas sganzini y est nombreux. Foudia eminentissima est commun dans les forêts plantées de bananiers sous les arbres.

\section{Introduction}

This paper is a sequel to parts I and II, published in this journal in 1992. In 1985 and 1989 we surveyed the birds of Ngazidja (Grand Comoro), Comoro Islands, in the western Indian Ocean, in order to investigate the distribution and the status of the endemic species, to gain insight into the threats they face, and to explore options for their protection. Ngazidja has to Comoro endemic landbirds, 17 endemic subspecies of landbirds and about 19 non-endemic resident landbirds (for their origin, distribution, and English names, see Louette 1988). From data generated during these surveys and on earlier visits to the islands, we have established the geographical distributions and status of the endemics (Louette et al. 1988, Louette and Stevens 1992, Stevens et al. 1992). Some conservation actions have been proposed and initiated. The most suitable areas to establish nature reserves have been indicated (Louette et al. 1988) and an educational and awareness campaign for bird protection launched (Louette et al. 1990, Soilih et al. 1993). 
On Ngazidja, the conservation of avian endemism is strongly linked to the preservation of forest, which in turn is strongly linked to human social and especially agricultural development on the island. Sound bird conservation proposals will therefore depend on an understanding of the relationships between the bird communities and their habitats and between these habitats and human activities.

On Ngazidja, the relationship between forest use and endemic bird preservation is of paramount importance. In a previous paper we assessed avian richness in relation to physical, vegetational and human variables of the environment (Stevens et al. 1993). Here we report on bird diversity in different habitat types and investigate the habitat preferences of individual species at Mount Karthala and La Grille (see also Louette and Stevens 1992), the two forested volcanoes on Ngazidja.

\section{Methods}

\section{Birds}

Data were gathered during point transect counts (Hustings et al. 1985) at 33 stations ( 17 in 1985 and 16 in 1989, nine of which were common to both years, but at Boboni counts were made along different paths; see map in Figure 1). Two observers counted for 10 periods of 15 minutes each from points at least $200 \mathrm{~m}$ apart. The counting points were distributed along a transect spaced out well enough to minimalize chances of double counting (although this was unavoidable in some loud calling species, e.g. the Courol Leptosomus discolor). Counts were performed either during the first three hours after sunrise or during the last two hours before sunset. At each point we noted numbers of birds seen or heard, their numbers, their location in the vegetation and their specific activity.

The counts were undertaken by ourselves and D. Vangeluwe. All were familiar with the local birds, having studied them either alive in the field or from illustrations and song recordings intensively beforehand. More details of field methods and location of stations are in Bijnens et al. (1987), Louette and Stevens (1992), Stevens et al. (1992, 1993).

Not all birds present on the island were detected during the counts, notably the nocturnal Karthala Scops Owl Otus pauliani (see Herremans et al. 1991), which is omitted from these analyses.

\section{Habitats}

Table 1 gives a brief description of the stations. They were spread out around Mount Karthala at all altitudinal levels from $0-2,000 \mathrm{~m}$ and on all sides of the mountain. Most of them were situated in the forest girdle. The other habitat types were sampled less representatively. Two counting stations were located on La Grille, the northern volcano. For the main analyses all counting stations were grouped into 12 habitat types (A-L, Table 2) selected on their field characteristics.

Human activities in the forest are very diverse. We therefore grouped the stations in the various forest types according to the human activity prevalent at each (the intact mature and pioneer forests we consider not to be man-altered). However, grouping such a variety of stations into categories runs the risk of attributing all differences between groups to the crude variables used to compose 
them, so we also analysed the relationships between bird richness and physical, vegetational and human variables, based on data from each station (Stevens et al. 1993).

Pioneer forests are found on recent lava flows and intact mature forests grow on older soils with a rather thick organic litter layer. In logged forest the cutting of big trees had destroyed the forest structure: in one case the exploitation was continuing, in another it had ceased a few years ago, and in two it had ceased about 35 years ago. In planted forests the canopy is largely intact but the undergrowth replaced by bananas or taros.

Aspect of the site influences both bird species diversity and the degree of endemism in the Comoros (Stevens et al. 1993). The pioneer forest and the intact mature forest stations possess different aspects. All stations with logged forest are situated on the southern and western slopes of the Karthala volcano.

\section{Analyses}

Since the abundance of species is different in various circumstances we used an index to describe bird diversity. We calculated bird species diversity (BSD) for each habitat type as the Shannon-Wiener diversity index (Pielou 1983)

$$
\mathrm{H}^{\prime}=-p_{i} \ln p_{i}
$$

in which $p_{i}$ is the proportion of individuals found in the $i$ th species. An advantage of this index is its wide use in ornithology, permitting comparison between various studies. This total BSD is composed of the proportions of endemic species, endemic subspecies and non-endemic species. The level of endemism is taken from Louette (1988).

To present the structure of the bird diversity more visually, we used Magurran's (1988) log-abundance/species-sequence distributions. In these graphs the logarithm of the abundance of each species is plotted against its sequence, permitting the detailed observation of bird distribution in relation to the species numbers. Various distributions can be compared in the same graph. We present the averages for all stations of each habitat type.

From the bird frequencies in each habitat type, a dendrogram with a Ward's error sum cluster analysis on Euclidian distances was calculated (Ward 1963, Grimm 1987).

To investigate the habitat selection of individual species we defined habitat width as the habitat-diversity index (Shannon-Wiener index) for each species over 12 habitat types (Magurran 1988) and subdivided this width to identify the contribution from each habitat type. We compared the proportions of counting points with and without the species between different habitat types by a Kruskal-Wallis one-way analysis of variance (Siegel 1956). If significant, we accept that the species selects among the different habitat types.

\section{Results}

\section{Bird species richness}

Table 3 gives the taxonomic status of each bird species and a species-by-habitat matrix showing the mean number of individuals counted per counting station. Table 4 summarizes these data. 


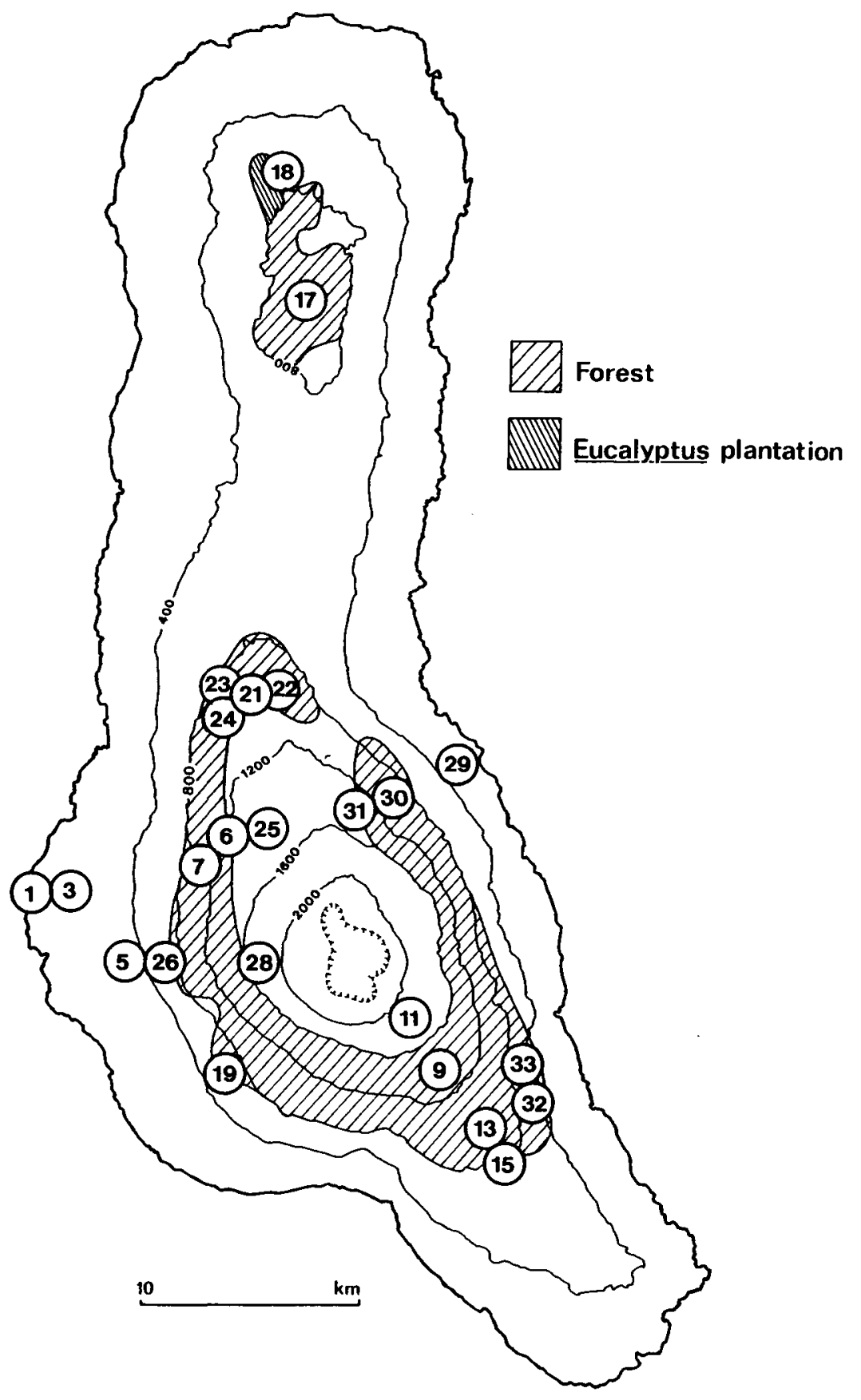

Figure 1. Map of the 33 stations (each described in Table 1). 
Table 1. Description of bird counting stations on Ngazidja.

\begin{tabular}{|c|c|c|}
\hline $\begin{array}{l}\text { Station } \\
\text { Number }\end{array}$ & Name & Description \\
\hline $1+2$ & Moroni Centre & Well wooded parts north of Moroni \\
\hline $3+4$ & Moroni Plantation & $\begin{array}{l}\text { Mainly tree crops (coconut, mango, jack-fruit), bananas and } \\
\text { cassava }\end{array}$ \\
\hline 5 & Mvouni & $\begin{array}{l}\text { Tree crops (coconut, avocado, jack-fruit); relatively open } \\
\text { country with vegetable and fruit gardens }\end{array}$ \\
\hline 6 & M'Lima Manda North & Well grown older pioneer forest \\
\hline $7+8$ & M'Lima Manda South & Badly degraded mature primary forest \\
\hline $9+10$ & Peter-Lut & Pristine primary forest \\
\hline $11+12$ & M'Lima Sanga & Tree heath and herbaceous vegetation above forest \\
\hline $13+14$ & M'Lima Mani North & $\begin{array}{l}\text { Badly degraded primary forest due to ring barking and } \\
\text { banana and taro plantation }\end{array}$ \\
\hline $15+16$ & M'Lima Mani South & Young pioneer forest on recent rocky lava \\
\hline 17 & La Grille Forest & $\begin{array}{l}\text { Very badly degraded mature forest due to banana and taro } \\
\text { plantations }\end{array}$ \\
\hline 18 & La Grille Eucalyptus & 5o-year old plantation \\
\hline $19+20$ & Nioumbadjou & $\begin{array}{l}\text { Badly degraded mature primary forest; active logging in } 1985 \text {, } \\
\text { abandoned in } 1989\end{array}$ \\
\hline 21 & Bahani & Badly degraded primary forest with banana plantation \\
\hline 22 & Lac & $\begin{array}{l}\text { Patches of degraded primary forest, well grown older pioneer } \\
\text { woodland and some open grassy areas }\end{array}$ \\
\hline 23 & Malakoff & $\begin{array}{l}\text { Open grassy areas with patches of degraded primary and well } \\
\text { grown pioneer forest }\end{array}$ \\
\hline 24 & Grotte & Medium-age open pioneer woodland \\
\hline 25 & Middle-North & Forest patches, partially burnt tree heath and grazed pasture \\
\hline $26+27$ & Boboni & $\begin{array}{l}\text { Mature primary forest badly degraded by logging and banana } \\
\text { plantations }\end{array}$ \\
\hline 28 & La Convalescence & Mature primary forest, tree heath and clearings \\
\hline 29 & Idjikounzi Low & Open country with grassland, gardens and wooded ravines \\
\hline 30 & Idjikounzi Middle & $\begin{array}{l}\text { Degraded mature primary forest, partly burnt, partly planted } \\
\text { with bananas and taro }\end{array}$ \\
\hline 31 & Idjikounzi High & Virtually pristine mature primary forest \\
\hline 32 & Tsinimoipanga South & Mature primary forest badly degraded by banana plantations \\
\hline 33 & Tsinimoipanga North & $\begin{array}{l}\text { Patches of mature primary forest degraded by banana } \\
\text { plantations alternating with gardens }\end{array}$ \\
\hline
\end{tabular}

Table 2. The habitat types distinguished.

\begin{tabular}{ll}
\hline Habitat type & Station numbers \\
\hline A Intact mature forest & $9,10,28,31$ \\
B Pioneer forest & $6,15,16,24$ \\
C Logged forest & $19,20,26,27$ \\
D Planted forest south and west & $7,8,13,14$ \\
E Planted forest north & $\mathbf{2 1}, 22,23,25$ \\
F Planted forest east & $30,32,33$ \\
G La Grille forest & 17 \\
H La Grille Eucalyptus & 18 \\
I Open country low & 5,29 \\
J Open country high & 11,12 \\
K Moroni centre & 1,2 \\
L Moroni Plantation & 3,4 \\
\hline
\end{tabular}

Station numbers as in Table 1 . 


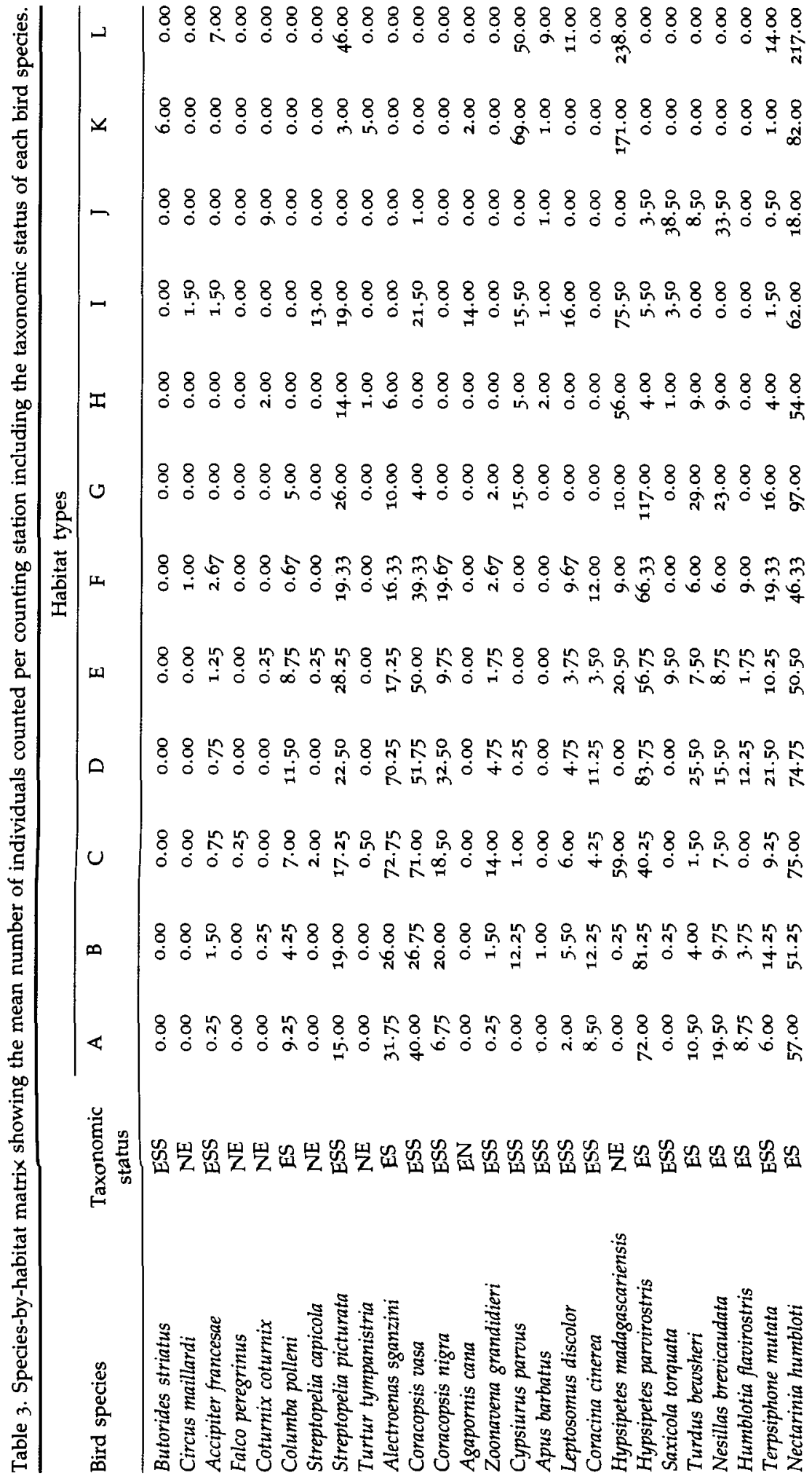


8888888888

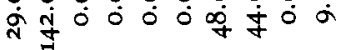

8888888888

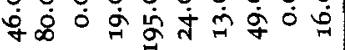

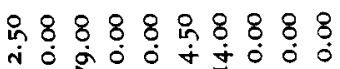
نं 888888 은 8 은

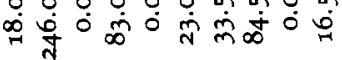
8888888888

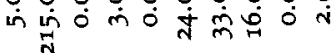

8888888888

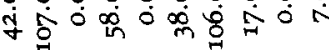

ติ8 $888 \% 8$ 응 i

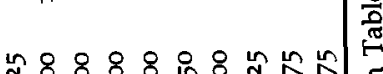

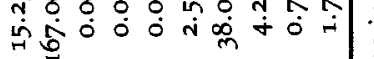
8 in 888 ํㅛ 888

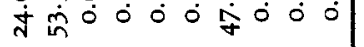

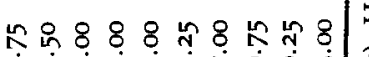

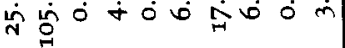

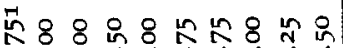
ம் 뇨8888 2888

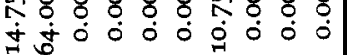

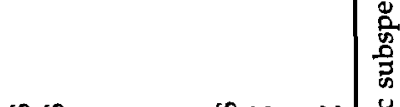

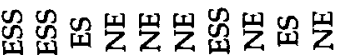

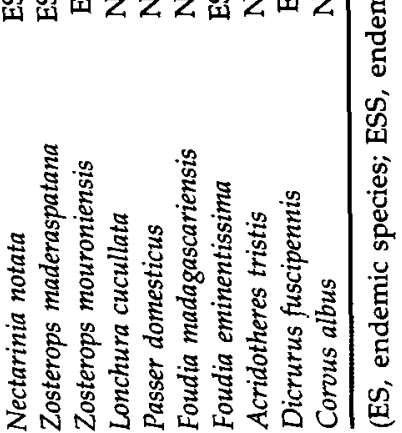

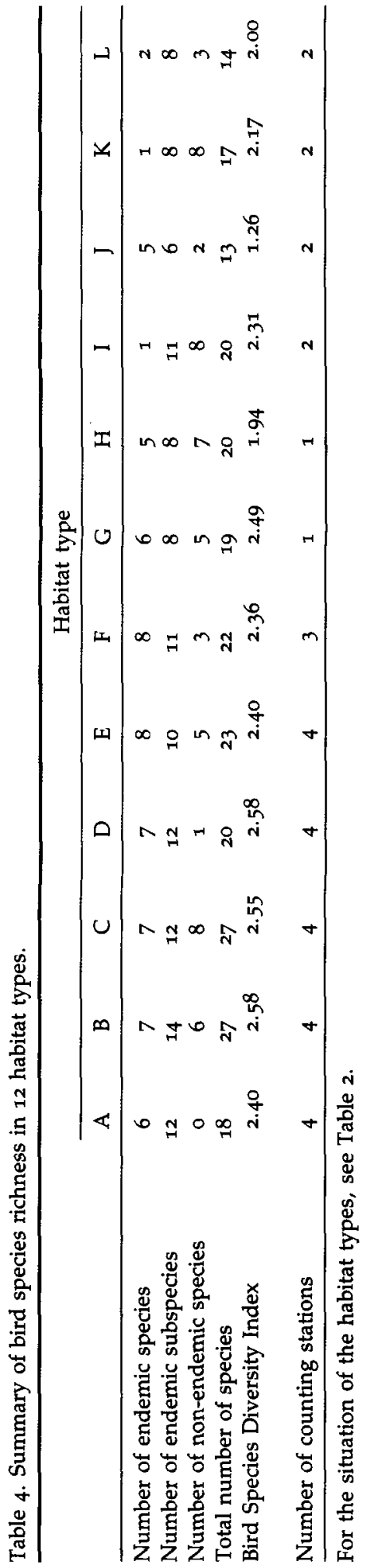


The number of endemic species in the forests on Mount Karthala varies between 6 and 8 . It is striking that this number is lowest in the intact mature forests. On La Grille the number of endemic species is also low; in open country and in Moroni it is even smaller. On La Grille the number of endemic subspecies is markedly lower than in the forests on Mount Karthala. The number of nonendemic species in the different habitat types varies between $o$ and 8 . Most important features are, on the one hand, the absence of non-endemic species in the intact mature forests and, on the other, only one species in the planted forests on the south and west slope. Also striking is the relatively high number of non-endemic species in the Eucalyptus plantation on La Grille.

The total number of species varies considerably among the forest types: between 18 and 27 on Mount Karthala. It is striking that the lowest number occurs in the intact mature forest, and the highest in the pioneer forest and the logged forest. The number of species on La Grille is also relatively low.

\section{Bird diversity indices}

Figure 2 gives the total BSD and the proportion of BSD due to endemic species, endemic subspecies and non-endemics for each habitat type. The total BSD is of the same order of magnitude for all forest types on Mount Karthala (KruskalWallis one-way analysis of variance: $H=9.4, d f=5, P<0.1$ ). Within the forest types the BSD of the intact mature forests and the planted forests on the southern and western slopes reflects a higher proportion of endemic species because non-endemics are (almost; see Table 4) lacking. In the other forests on Mount

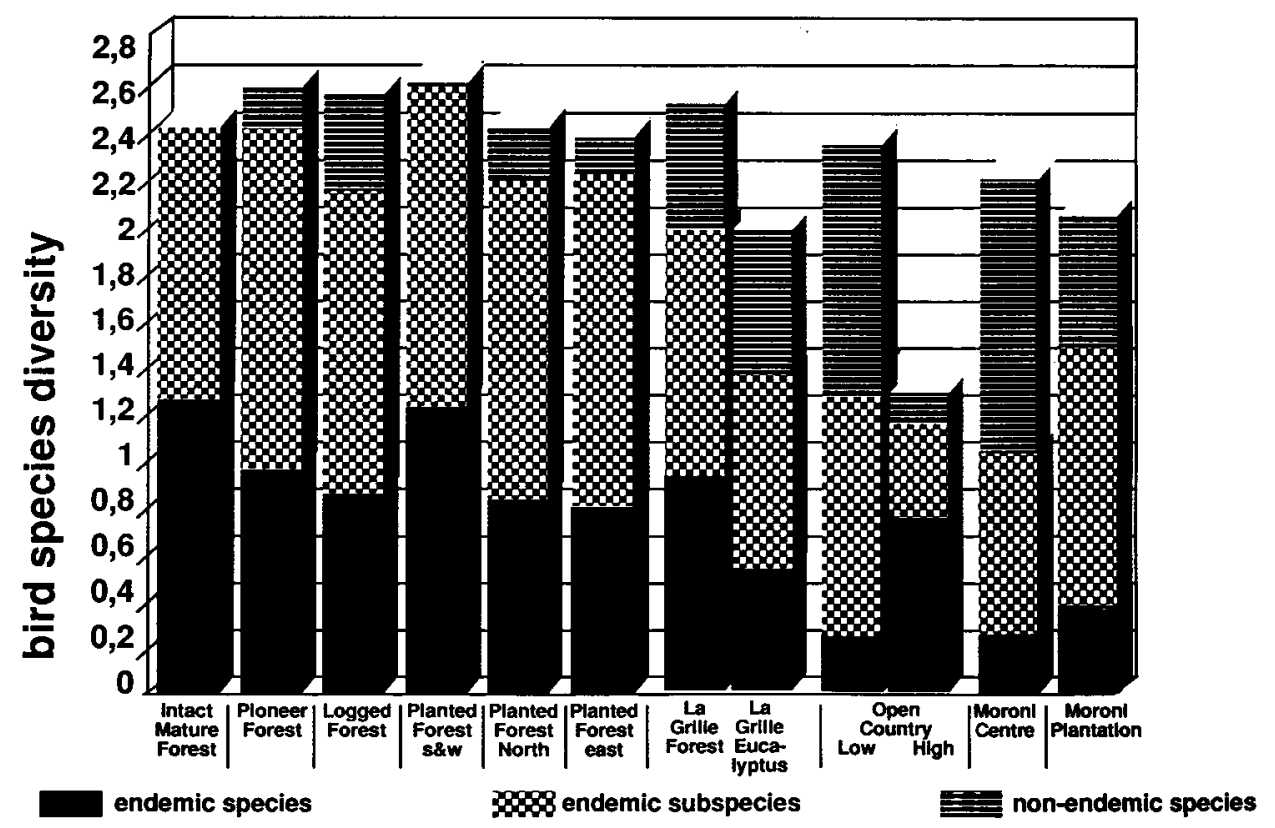

Figure 2. The total BSD for each habitat type, with the portions of endemic species, endemic subspecies and non-endemic species. 
Karthala the non-endemics contribute slightly to the BSD, least so in the planted forests on the eastern slope, more in the pioneer forest and in the planted forests on the northern slope, and most in the logged forests, irrespective of their orientation (either west or south). These latter aspects yield the largest amount of endemic species in the planted forests.

The forest station on La Grille has the same total BSD as the forest types on Mount Karthala with the highest diversity indices, but the proportion of non-endemics is higher on La Grille (only due to five species, see Table 4). In the Eucalyptus plantations the total BSD is much lower than in the adjacent forest, owing to the low numbers of individuals from the endemics. In open country the proportion of non-endemics is low at high but high at low altitudes. For the endemic species the opposite is the case, but the proportion of endemic subspecies is similar. In the centre of Moroni and in the plantations nearby, endemic species are proportionately far fewer than non-endemics.

Figure 3 presents the log-abundance/species-sequence distributions of the different forest types on the slopes of Mount Karthala, with decreasing abundance from left to right (the angle of the line of the graph is steeper with decreasing diversity). It is noteworthy that while some differences occur in the total bird abundance, all forest types show nearly the same slope in the general position between the fifth and fifteenth species. We cannot explain this fact; possibly it results from the field methods used.

On the right of the distribution sequence the variation is due to differences in the total number of bird species. The number of species is lowest in the

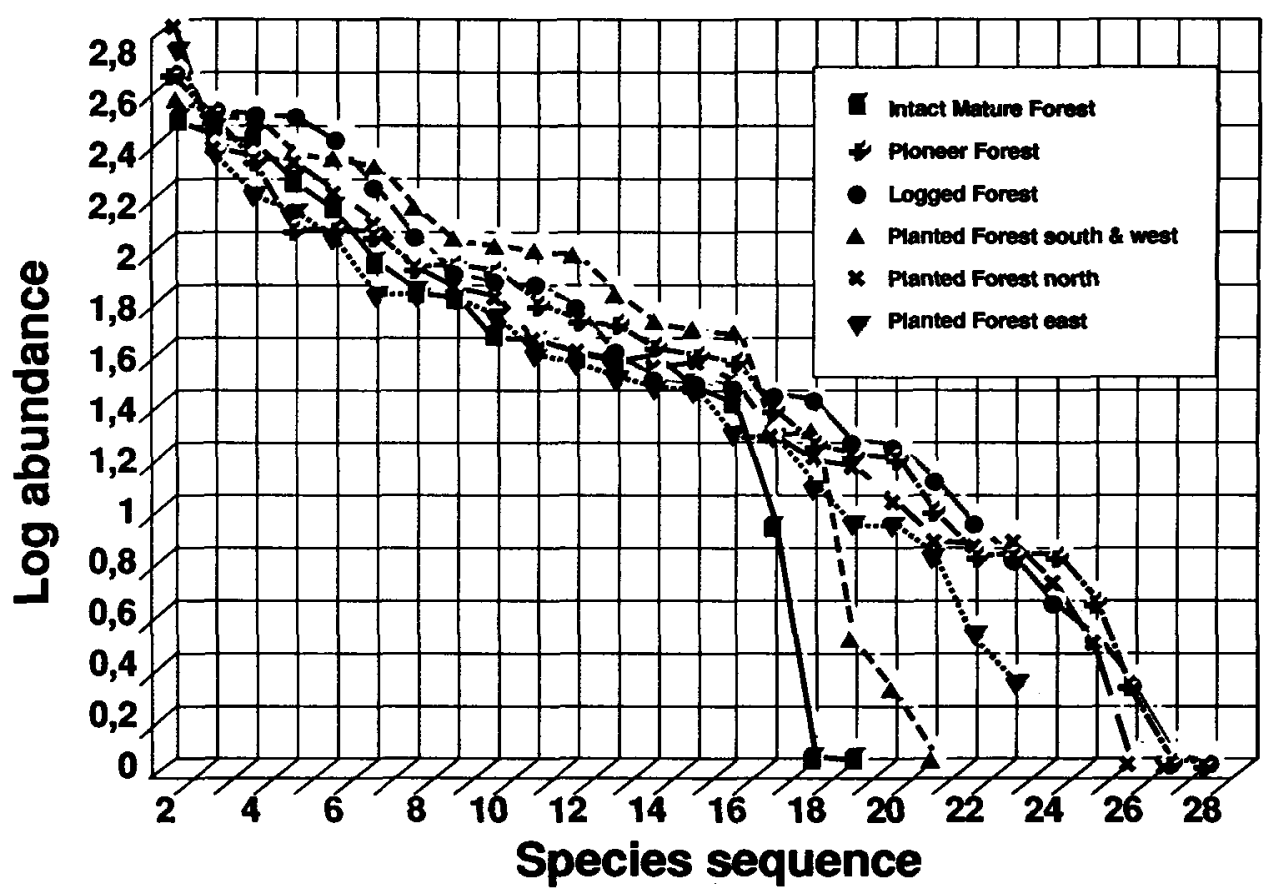

Figure 3. The log-abundance/species-sequence distribution for all forest types on Mount Karthala. Explanation, see text. 
mature forest and in the planted forests on the southern and western slopes, where, however, we found the highest number of endemic species (Stevens $e t$ al. 1993) and the highest BSD owing to endemic species.

On the left of the graph, in some forest types, for example in the planted forests on the northern and eastern slopes and also in the pioneer forest, we notice a strong dominance, mostly by one species only (almost always the Madagascar White-eye Zosterops maderaspatana kirki), indicated by an upward "nod" in the distribution. It is also striking that in the planted forests on the southern and western slopes and in the intact mature forests there are no dominant species. In these habitat types several of the most frequent species are nearly equally abundant.

The forest and Eucalyptus stations on La Grille are also clearly different in their log-abundance/species-sequence distribution (Figure 4). The shape of the forest graph is comparable to those for Mount Karthala. In the Eucalyptus, although the same number of species was present, all were less abundant with the exception of the Madagascar White-eye, which was six times more abundant than the second commonest species in this artificial habitat.

The relationships between bird communities and habitat types are shown as a dendrogram in Figure 5 . One group of habitat types includes the counting stations of Moroni and La Grille, characterized by the large number of nonendemic species. The open country at high altitude is completely aberrant, owing to the dominance of the Karthala White-eye Zosterops mouroniensis, a stenotopic endemic species absent from all other stations. All forest types on

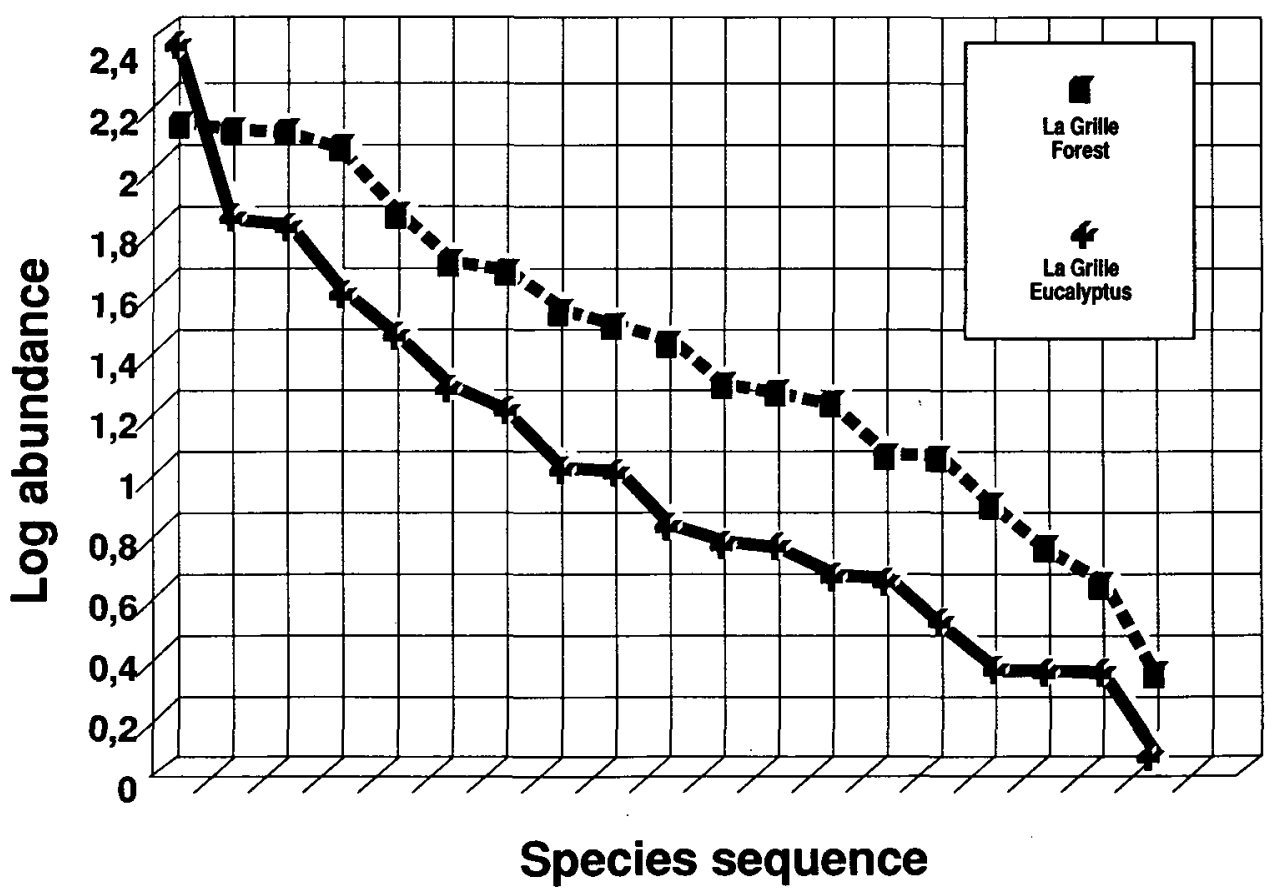

Figure 4. The log-abundance/species-sequence distribution for the forest and Eucalyptus counting station on La Grille. For explanation, see text. 


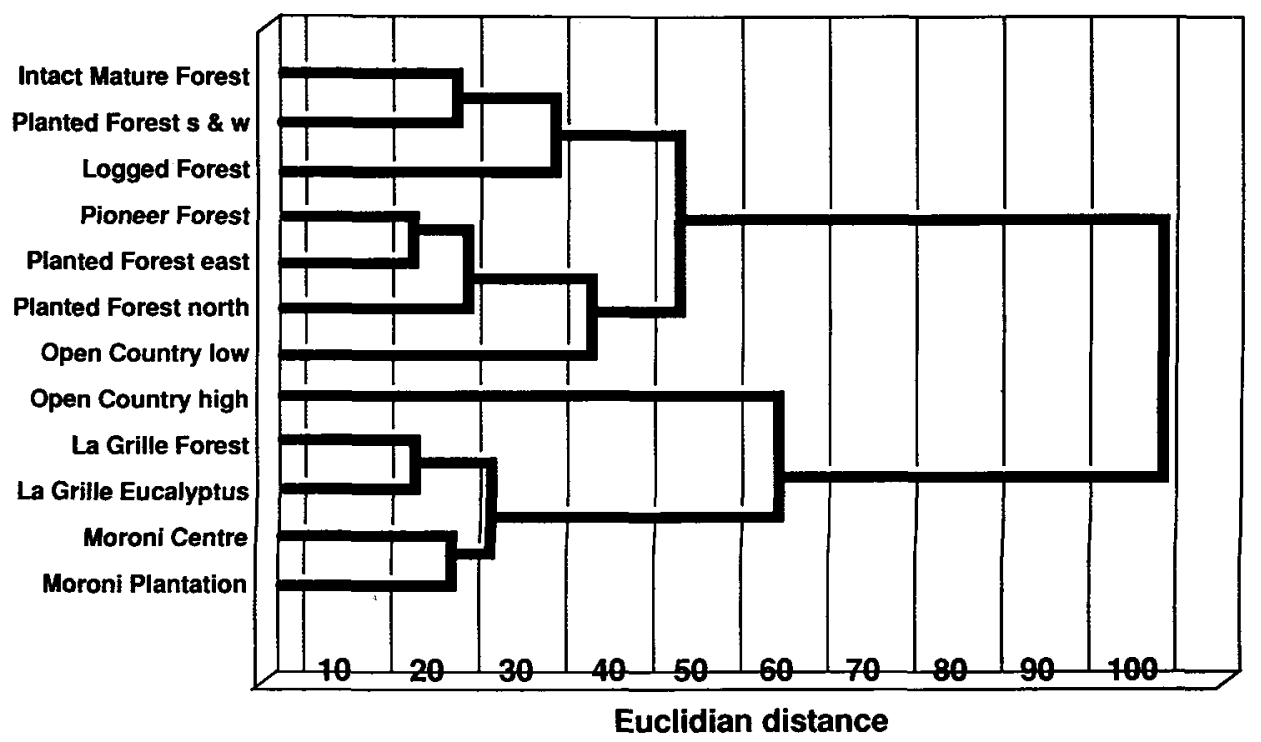

Figure 5. Similarity dendrogram on the basis of Euclidian distances for all habitat types on Ngazidja.

Mount Karthala are clustered together with the open country at low altitude, the dendrogram clearly showing the resemblance between the intact mature forests and the planted forests on the southern and western slopes. Also, the logged forests are clearly related to these two forest types, notwithstanding their relatively high BSD component of non-endemic species. The pioneer forests resemble the planted forests on the northern slopes.

\section{Habitat selection}

The mean habitat width calculation yields $1.531 \pm 0.678$ for the endemic species, $1.706 \pm 0.587$ for the endemic subspecies, and $0.980 \pm 0.705$ for the nonendemics. The habitat width is relatively small in non-endemics compared with endemic species and subspecies (Kruskal-Wallis: $H: 5.98, P<0.05, d f=2$ ). The difference between endemic species and subspecies is not significant.

Table 5 lists the species whose habitat width is larger than 1.00 and which show no clear preference for open country, their total habitat width, the proportion for each forest type and the significance level of their habitat selection (Kruskal-Wallis one-way analysis of variance). Species are arranged in descending order of habitat width within their groups.

Four of the seven endemic species actively select between forest types on Mount Karthala, and four of the eleven endemic subspecies do likewise, but none of the four non-endemics does so. In the group of endemic species the Grand Comoro Brush-warbler Nesillas brevicaudata prefers mature forests and planted forests on the southern and western slopes of Mount Karthala, and clearly avoids logged forests. The Comoro Thrush Turdus bewsheri has nearly the same preferences but its reluctance to enter logged forests is even more 


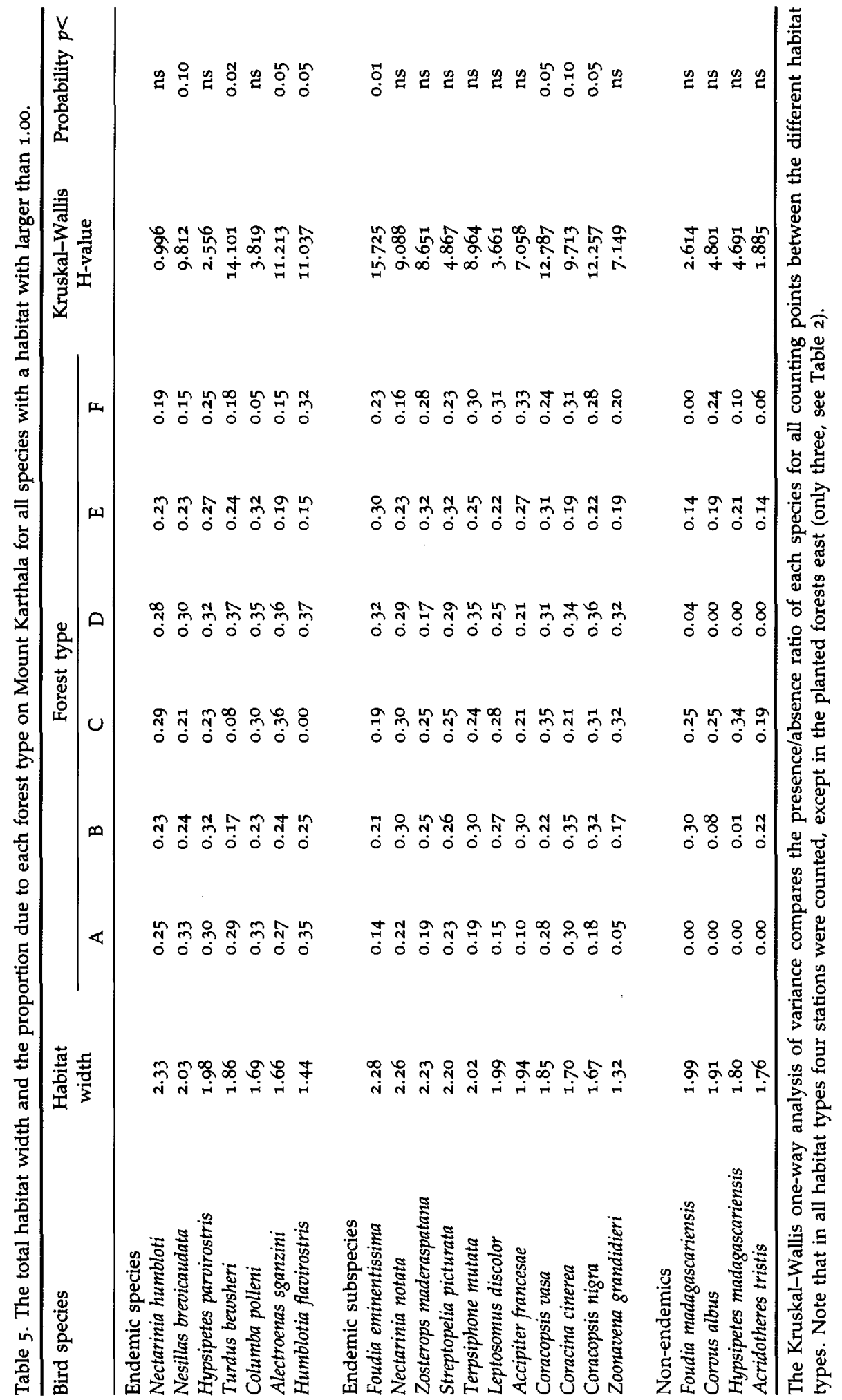


clear. Humblot's Flycatcher Humblotia flavirostris, with the same preferred forest types, was totally absent from logged forest. By contrast, the Comoro Blue Pigeon Alectroenas sganzini does well in the planted forests on the southern and western slopes, but it is also very abundant in the logged forests.

All but one of the endemic species prefer the intact mature forests over the pioneer forests. Remarkably, the opposite is true for the endemic subspecies. For all but one of them the pioneer forests are preferred over the intact mature forests: For some species this is striking, e.g. Frances's Sparrowhawk Accipiter francesae, Madagascar Spine-tailed Swift Zoonavena grandidieri and Lesser Vasa Parrot Coracopsis nigra. The endemic subspecies also differ in their forest type selection.

Unique habitat selection is displayed by the Comoro Fody Foudia eminentissima, which is more numerous on the slopes of Mount Karthala in each planted forest type than in any other natural (mature or pioneer) forest type or in the logged forests. Foudia eminentissima, Long-billed Green Sunbird Nectarinia notata and Greater Vasa Parrot Coracopsis vasa decrease in the planted forests from the southern and western slopes over the northern towards the eastern slopes, but Accipiter francesae seems to show the opposite trend (though not significant). Logging probably favours C. vasa, but not the Ashy Cuckoo-shrike Coracina cinerea: we suggest that short-term changes in human exploitation heavily influence the latter (Stevens et al. 1992).

Of the non-endemic species it is striking that none occurs in the intact mature forests, but in the pioneer forest the Madagascar Fody Foudia madagascariensis, Common Myna Acridotheres tristis and Pied Crow Corvus albus are found. In the logged forests all four non-endemics are well represented; in the forests planted with bananas they are less frequent.

\section{Discussion}

\section{Bird diversity}

Total BSD is of the same order of magnitude for all forest types. In the intact mature forest it is a little lower (but not significantly) than in most other forest types. In India Daniëls et al. (1990) even found an increase after forests were disturbed. Cornell (1978) related high levels of diversity to disturbed conditions and lower levels to stability within the tropics: disturbance does not necessarily result in a lower BSD.

The differences in levels of endemism in the different habitat types are interesting. Altitude and vegetation structure influence the composition of the bird community and the proportions of endemic species, endemic subspecies and non-endemic species. Non-endemic species are absent from the dense intact mature forests at higher altitude but they represent a certain amount of the BSD in the pioneer forests, where the vegetation is more open and less luxuriant, the non-endemics being concentrated mainly at lower altitudes. Endemic species prefer denser vegetation at higher altitudes, non-endemic species prefer more open vegetation and lower altitudes, and endemic species are intermediate (Stevens et al. 1993). Within planted forests endemic species are better represented in most luxurious stands on the southern and western slopes, less so on the northern and eastern slopes. 
The good representation of the non-endemic avifauna in logged forests may be due to their occurrence at lower altitude, or to the creation of large clearings during logging activities, or to a combination of both factors. Sakai (1988) reported a lower bird abundance and species-richness in logged forest plots than in adjacent control plots in Hawaii, but in New South Wales, Australia, Pattermore and Kikkawa (1975) reported that, when logged areas revert back to mature rainforest, bird species composition and abundance resemble those of the intact areas. Our comparison of bird abundances between 1985 and 1989 in logged stations at Nioumbadjou seems to confirm this (Stevens et al. 1992). In the dendrogram (Figure 5) the logged forests are close to the intact mature forests and the planted forests on the southern and western slopes, despite the difference in the amount of non-endemics. However, since all logged forests are situated on the southern and western slopes of Mount Karthala, it is probable that aspect is responsible for the resemblance in bird species composition, especially for the endemic species and subspecies.

The case of La Grille is interesting. The shape of the log-abundance/speciessequence distribution of the forest station at La Grille is comparable to those of the planted forests on the southern and western slopes of Mount Karthala. However, the species composition is clearly different, as is apparent from the dendrogram. Some endemic species are absent from La Grille, possibly because the isolation and the smallness of the forest patch there do not permit viable populations (Louette et al. 1989). Apparently they are replaced by endemic subspecies and non-endemics to attain a BSD and log-abundance/species-sequence distribution comparable with the "best" forests on Mount Karthala.

In the Eucalyptus plantation at La Grille the number of endemic species and endemic subspecies is not drastically lower than in the other forests, but the BSD due to the endemics is clearly lower. Also the total BSD is markedly lower. In India Daniëls et al. (1990) also found a lower BSD in Eucalyptus plantations than in all other intact or disturbed forests. The strong dominance of one species, Zosterops maderaspatana, is comparable to Daniëls et al.'s observations and suggests low food availability in this exotic vegetation. Outside Australia all Eucalyptus plantations are poor in birds because they lack their typical insect fauna, which would serve as a food supply (Pina 1988, Blondel 1990). We conclude that the plantation of Eucalyptus on La Grille is worthless for the preservation of bird endemism. The view that planting Eucalyptus on the slopes of Mount Karthala would allow endemic bird species to spread into this habitat type is clearly fallacious.

The dominance of a species of white-eye in Eucalyptus plantations on Ngazidja is not peculiar. At most stations it was strongly dominant, mostly in more open forest types in drier regions or disturbed situations. Analogous observations have been reported for congeners on the Mascarenes (Gill 1971), and in Hawaii a white-eye was the first to recolonize forest areas after treatment of the vegetation (Berger 1981, Scott et al. 1986, Sakai 1988) because of its omnivory and habit of forming large feeding flocks (see Sakai 1988).

In open country at high altitude $Z$. maderaspatana kirki is replaced by the parapatric Z. mouroniensis. In one case the Greater Vasa Parrot was dominant (Middle-North), probably owing to the presence of a roost near the counting 
plots; in Moroni Centre the House Sparrow Passer domesticus was dominant. The species (mostly Hypsipetes sp.) most abundant in the undominated stations never themselves became dominant.

When comparing the log-abundance/species-sequence distribution for the mature intact forests with that for the pioneer forests, the former merely agrees with that expected for mature ecosystems in supposed equilibrium, with a more homogeneous distribution of sources over the species. The distribution of pioneer forests suggests that expected for young succession stages, not yet in equilibrium (Magurran 1988, Wiens 1989). In this respect the structure of the bird community in the intact forest types on Mount Karthala seems to fit what one would expect on a theoretical basis. The shape of the distribution of the mature forests with a nearly intact canopy but with their undergrowth damaged by planting bananas and/or taros and situated on the southern and western slope of Mount Karthala does not differ markedly from the intact mature forests. Their close relationship in bird species composition is also clear from their position in the similarity dendrogram. Apparently they can sustain their avian community quite well after this kind of human impact. The group of planted forests on the other slopes of Mount Karthala has slightly different log-abundance/speciessequence distributions and resembles more the pioneer forests (especially those on the northern slope). These relationships are also indicated by the positions in the similarity dendrogram.

The fact that BSD is highly influenced by the aspect of the station (especially for the endemic species) indicates the importance of this parameter in planning for bird preservation (Stevens et al. 1993): the southern and western slopes are richer than the northern and eastern slopes. However, for a definitive analysis of the effect of different parameters - physical, vegetational (Stevens et al. 1993) and human - we lack enough data on intact mature forests with different aspects and altitudes. Possibly the variety and size of habitats necessary to test all possible variables are no longer present.

\section{Habitat selection}

That the habitat width of the non-endemic species proved smaller than that of the endemics is not surprising, since most of the habitat types distinguished are situated in different kinds of forest. Furthermore, non-endemic species are predominantly open-country birds. The fact that the habitat width of endemic subspecies does not differ significantly from that of endemic species is more surprising, since they are supposed to be less stenotopic (Stevens et al. 1993).

At the species level and within the group of endemic species and subspecies, important differences in forest type selection occur. For example, the absence (or more likely the disappearance if we compare with data from Benson 1960) of Humblotia flavirostris, Turdus bewsheri and Nesillas brevicaudata from the logged forests, and the high abundance in them of Alectroenas sganzini, indicates that different species react in different ways to logging. A remarkable observation is that Foudia eminentissima is more numerous in planted forests. This species is frequently seen feeding on the flowers of banana-trees, which may explain the habitat preference we observed. 
Obviously, a change in vegetation can make a region more favourable for one species and less so for another. Logging is probably unfavourable for $\mathrm{H}$. flavirostris, T. bewsheri and N. brevicaudata but favourable for A. sganzini. Planting bananas under the canopy probably benefits $F$. eminentissima.

The most striking differences between forest types are visible at the species level. The effects of different human impacts on the level of BSD are less pronounced, while those on the proportion of endemics in the total BSD are more clear-cut.

All endemic species are more numerous in mature forests, while all but one endemic subspecies are so in pioneer forest. This observation parallels the differences in relationhip of both groups to the vegetational structure of their habitats (Stevens et al. 1993). The vegetation structure of the pioneer forest is probably intermediate between open country and mature forests.

The relative preference of endemic subspecies for these pioneer forests may indicate that they played an important role in the evolutionary history of the island. Because of Karthala's volcanic activity, pioneer forest has probably always been present on the island. Open-country birds could establish themselves thanks to the successional vegetational stages following eruptions. When evolving from a recent arrival into an endemic subspecies and then species, the habitat preferences of the bird may have altered from open habitat into pioneer and later mature forest. Since the endemic species and subspecies are all present in the pioneer forest nowadays, and since this forest type is not (yet) exploited by humans and is marginal for agriculture, this habitat type can play an important role in a bird conservation strategy on the island.

The non-endemic species group avoids mature and other forests with dense tree cover. The lower BSD and absence of the non-endemic group in the more open vegetation at Middle-North suggest that altitude may be the limiting factor in the spread of the birds. Interspecific competition between non-endemic and endemic taxa has probably led to the striking parapatry between some endemic species and their non-endemic counterparts (Hypsipetes spp.: see Louette and Herremans 1985). Other congeners are sympatric but differ ecologically (Foudia spp., Streptopelia spp.: Bijnens et al. 1987).

The island as a whole is of course composed of a mosaic of different habitats. Our conclusions are strongly dependent on the representativeness of the stations we used. In most cases we were satisfied that this was the case, but in some at the lower edge of the forest, where human exploitation is "climbing" along paths in the forest, we were not. Here we were compelled to count along these paths because the forest is virtually inaccessible. At these stations the composition of the bird community might have been influenced by the (possibly) more intact adjacent forests, resulting in a possible underestimation of the impact of forest exploitation; Daniëls et al. (1990) found that the composition of the bird community in a plantation was influenced by the quality of the neighbouring natural vegetation patches.

It must also be stressed that our data concern only counts outside the breeding season for most species. Some species have special habitat requirements for breeding. The preference of Foudia eminentissima for planted forests with many banana trees clearly has to do with its feeding behaviour. 


\section{Some conclusions with respect to the conservation of endemism}

1. Both mature forests and pioneer forest can play a major role in the preservation of endemism on Ngazidja. Mature forests are important for endemic species, pioneer forests for endemic subspecies, although both occur in each forest type. The importance of pioneer forests is interesting because this forest type is seemingly unattractive for human exploitation, especially agriculture, as it lacks a fertile upper soil.

2. Different kinds of human impact have a different effect on the bird community. This is clearly the case at the level of the individual species, although much less so with the total levels of BSD in different habitat types, and only slightly so concerning the proportion of endemic taxa in the bird community. In logged forests Humblotia flavirostris, Turdus bewsheri and Nesillas brevicaudata are absent or scarce, but Alectroenas sganzini is numerous. In forests planted with bananas Foudia eminentissima is very numerous.

3. Creation of Eucalyptus plantations seems useless for bird preservation. Only Zosterops maderaspatana is very numerous there.

\section{Acknowledgements}

ICBP - now BirdLife International - provided most of the funding for the fieldwork. We also thank D. De Baere for calculating the dendrogram, and A. Reygel and L. Tits for the construction of the figures.

\section{References}

Benson, C. W. (1960) The birds of the Comoro Islands: results of the British Ornithologists' Union Centenary Expedition 1958. Ibis 103b: 5-106.

Berger, A. J. (1981) Hawaiian birdlife. Honolulu: University Press of Hawaii.

Bijnens, L., Stevens, J., Janssens, L. and Louette, M. (1987) Community structure of Grand Comoro land birds with special reference to the ecology of congeneric species. Reoue Zool. Afr. 101: 221-232.

Blondel, J. (1990) Long-term studies in bird communities and populations in mainland and island Mediterranean forests. Pp.167-182 in A. Keast, ed. Biogeography and ecology of forest bird communities. The Hague: Academic Publishing.

Connell, J. H. (1978) Diversity in tropical rainforest and coral reefs. Science 199: 13021310.

Daniëls, R. J. R., Hedge, M. and Gadgil, M. (1990) Birds of man-made ecosystems: the plantations. Proc. Indian Acad. Sci. (Anim. Sci.) 99(1): 79-89.

Gill, F. B. (1971) Ecology and evolution of the Mascarene white-eyes, Zosterops borbonica and Zosterops olivacea. Auk 88: 35-60.

Grimm, E. C. (1987) CONISS: a FORTRAN 77 program for stratigraphically constrained cluster analysis by the method of incremental sum of squares. Comput. Geosci. 13: 13-35.

Herremans, M., Louette, M. and Stevens, J. (1991) Conservation status and vocal and morphological description of the Grand Comoro Scops Owl Otus pauliani Benson 1960. Bird Conserv. Internatn. 1: 123-133.

Hustings, M. F. H., Kwak, R. G. M., Opdam, P. G. M. and Reynen, M. J. S. M. (1985) Vogelinventarisatie, achtergronden, richtlijnen en verslaggeving. Wageningen: PUDOC. 
Louette, M. (1988) Les oiseaux des Comores. Ann. Mus. R. Afr. Centr., Zool. 255: 1-192.

Louette, M. and Herremans, M. (1985) Taxonomy and evolution in the bulbuls (Hypsipetes) on the Comoro Islands. Proc. Internatn. Symp. Afric. Vert. Bonn: 407-423.

Louette, M., Bijnens, L., Stevens, J. and Janssens, L. (1989) Comparison of forest bird communities on Ngazidja and Mwali (Comoro Islands). Ostrich suppl. 14: 33-37.

Louette, M., Stevens, J., Bijnens, L. and Janssens, L. (1988) A survey of the endemic avifauna of the Comoro Islands. Cambridge, U.K.: International Council for Bird Preservation (Study Report 25).

Louette, M., Stevens, J., Herremans, M. and Vangeluwe, D. (1990) Conservation training and avifaunal inventories on the Comoro Islands. Unpublished.

Louette, M. and Stevens, J. (1992) Conserving the endemic birds of the Comoro Islands, I: general considerations on chances for survival. Bird Conserv. Internatn. 2: 61-80.

Magurran, A. E. (1988) Ecological diversity and its measurement. Cambridge, U.K.: Cambridge University Press.

Pattermore, V. and Kikkawa, J. (1975) Comparison of bird populations in logged and unlogged rainforest at Wiangarie State Forest, N.S.W. For. Comm. 37: 188-198.

Pielou, E. C. (1983) Populations and community ecology: principles and methods. New York: Gordon and Breach.

Pina, J. P. (1988) Birds in Eucalyptus plantations in Portugal. Acta Zool. Fenn. 26: 287-290. Sakai, H. F. (1988) Avian response to mechanical clearing of a native rainforest in Hawaii. Condor 90: 339-348.

Scott, J. M., Mountainspring, S., Ramsey, F. L. and Kepler, C. B. (1986) Forest bird communities of the Hawaiian Islands: their dynamics, ecology and conservation. Stud. Avian Biol. 9: 1-431.

Siegel, S. (1956) Nonparametric statistics for the behavioural sciences. New York: McGraw-Hill. Soilih, A., Louette, M., Meirte, D., Stevens, J. and Herremans, M. (1992) A public awareness campaign and bird conservation training on the Comoro Islands. Proc. 8 Pan-Afr. Orn. Congr. [Ann. Sci. Zool. Mus. Roy. Afrique Centr. 286]: 178.

Stevens, J., Herremans, M. and Louette, M. (1992) Conserving the endemic birds on the Comoro Islands, II.: population fluctuations on Ngazidja. Bird Conserv. Internatn. 2: $81-91$.

Stevens, J., Louette, M., Bijnens, L. and Herremans, M. (1993) Bird diversity on Ngazidja, Comoro Islands. Proc. 8 Pan-Afr. Orn. Congr. [Ann. Sci. Zool. Mus. Roy. Afrique Centr. 286]: 179-186.

Tramer, E. J. (1974) On latitudinal gradients in avian diversity. Condor 76: 123-130.

Ward, J. H. (1963) Hierarchical grouping to optimize an objective function. J. Amer. Stat. Assoc. 58 (301): 236-244.

Wiens, J. A. (1989) The ecology of bird communities, 1: Foundations and patterns. Cambridge: Cambridge University Press.

\section{JAN STEVENS, MICHEL LOUETTE, LUC BIJNENS}

Royal Museum for Central-Africa, B-3080 Tervuren, Belgium

\section{MARC HERREMANS}

Department of Wildlife and National Parks (Ornithology Section), P. O. Box 131, Gaborone, Botswana 